\title{
Upaya Meningkatkan Prestasi Belajar \\ Mata Kuliah Ekonomi Pembangunan melalui Pendekatan Kontekstual (Contextual Teaching and Learning) \\ Mahasiswa Tingkat II Program Studi Pendidikan Ekonomi Semester Genap 2018/2019
}

\author{
Mochamad Muchson \\ mochamad.muchson@gmail.com \\ Magister Pendidikan Ekonomi \\ Program Pasca Sarjana \\ Universitas Nusantara PGRI Kediri
}

\begin{abstract}
Abstrak
Tujuan dari penelitian ini adalah upaya untuk meningkatkan motivasi, aktivitas dan prestasi belajar mahasiswa melalui penerapan pendekatan pembelajaran kontekstual (contextual teaching and learning). Metode penelitian menggunakan Penelitian Tindakan Kelas 3 siklus. Sampel penelitian adalah sampel jenuh dimana seluruh populasi menjadi anggota sampel. Instrumen penelitian menggunakan tes dan observasi. Teknik analisis data menggunakan statistik deskriptif. Hasil penelitian menunjukkan:1) Siklus pertama: motivasi dan aktivitas belajar mahasiswa berkategori cukup dilihat dari hasil test secara individu $40 \%$ mahasiswa berkategori cukup dan $60 \%$ mahasiswa berkategori baik. Dilihat dari tingkat ketuntasan belajar secara individu $60 \%$ mahasiswa sudah tuntas belajarnya dan apabila dilihat dari ketuntasan kelas ternyata belum tuntas belajarnya. Hal ini disebabkan karena mahasiswa belum terbiasa dengan metode kontekstual. Mahasiswa terbiasa dengan metode ceramah dimana dosen langsung menjelaskan materi kuliah sedang dalam pendekatan kontekstual mahasiswa memahami suatu materi mata kuliah melalui keterlibatan yang tinggi dalam pembelajaran; 2) Siklus kedua: dimana dosen memberi penekanan pada mahasiswa untuk meningkatkan keterlibatan dalam proses pembelajaran menunjukkan bahwa motivasi dan aktivitas belajar 60\% mahasiswa berkategori baik dan $40 \%$ mahasiswa berkategori baik sekali. Hal ini dilihat dari hasil test materi mata kuliah secara individu $60 \%$ mahasiswa berkategori baik dan $40 \%$ mahasiswa berkategori baik sekali. Dilihat dari tingkat ketuntasan belajar ternyata baik secara individu maupun secara kelas $100 \%$ mahasiswa sudah tuntas belajarnya. Hal ini disebabkan mahasiswa sudah beradaptasi dengan pembelajaran kontekstual sehingga motivasi, aktivitas dan nilai testnya meningkat; 3) Siklus ketiga dimana dosen bertindak sebagai motivator dan fasilitator dalam proses pembelajaran menunjukkan bahwa motivasi dan aktivitas belajar $20 \%$ mahasiswa berkategori baik dan $80 \%$ mahasiswa berkategori baik sekali. Berdasarkan hasil test materi mata kuliah secara individu 20\% mahasiswa berkategori baik dan $80 \%$ mahasiswa berkategori baik sekali. Dilihat dari tingkat ketuntasan belajar ternyata baik secara individu maupun secara kelas $100 \%$ mahasiswa sudah tuntas belajarnya. Hal ini disebabkan mahasiswa sudah terbiasa dengan pembelajaran kontekstual sehingga motivasi, aktivitas dan nilai testnya tinggi. Pembelajaran kontekstual dapat meningkatkan prestasi belajar karena: 1) Mahasiswa secara aktif terlibat

Peer reviewed under responsibility of Universitas Nusantara PGRI Kediri.

(c) 2020 Mochamad Muchson This is an open access article under the CC BY-SA license ( https://creativecommons.org/licenses/by-sa/4.0/ )
\end{abstract}


Jurnal PINUS: Jurnal Penelitian Inovasi Pembelajaran, 6 (1), 2020, Mochamad Muchson

dalam proses pembelajaran, 2) Mahasiswa belajar dari teman melalui kerja kelompok, diskusi, dan saling mengoreksi, 3) Pembelajaran dikaitkan dengan kehidupan nyata dan atau masalah yang disimulasikan, 4) Perilaku dibangun atas kesadaran diri, 5) Ketrampilan dikembangkan atas dasar pemahaman, 6) Hadiah untuk perilaku baik adalah kepuasan diri, 7) Mahasiswa menggunakan kemampuan berpikir kritis, terlibat penuh dalam mengupayakan terjadinya proses pembelajaran yang efektif, dan membawa skema masing-masing kedalam proses pembelajaran.

Kata Kunci : Pendekatan kontekstual, motivasi, aktivitas, prestasi belajar, motivator, fasilitator

\begin{abstract}
The purpose of this research is an attempt to increase the motivation, activities and learning achievements approach students through the application of learning contextual (contextual teaching and learning). The methodology using research class action 3 cycle. The sample sample is saturated where the whole population of being a sample. Research instruments using tests and observation. Analysis techniques data using descriptive statistics. The result showed: 1) First cycle: motivation and learning activity students category enough while seen from the test results individually $40 \%$ students category enough and $60 \%$ students category good. Seen from the result of learn individually $60 \%$ students has completed we study and if seen from result of class is not yet complete study. This is because students are not used by contextual method. students familiar with the talks where lecturer directly explained the materials are in a college student contextual understanding a matter lecture through the involvement high in learning. 2) Cycles both: where lecturer put the stress the students to improve involvement in learning shows that motivation and activity $60 \%$ students categorygood and $40 \%$ students categoryvery good. Being viewed from the test results matter lecture individually $60 \%$ students category good and $40 \%$ students category good. Seen from the result of study was either individually and $100 \%$ students have completed for the study. This is because students have adapted by learning contextual so motivation, activity and the test is increased value. 3) Where cycle third lecturer act as motivator and facilitators in learning shows that motivation and activity $20 \%$ students category good and $80 \%$ students category good. Being viewed from the test results matter lecture individually $20 \%$ students category good and $80 \%$ students category good. Seen from the result of study was either individually and $100 \%$ students has completed the study. This is due to students accustomed to that motivation, contextual learning and the high result of the test, contextual activity learning can improve performance study because: 1) students actively involved in learning, 2) students learning from friends through, working group, discussion and mutual correcting, 3) learning associated with the real and simulated or trouble, 4) behavior are built on self-awareness, 5) skills developed on the basis of understanding, 6) reward for good behavior is self-satisfaction, 7 ) students apply the think critically engage fully as effort of the learning effective, and bring into learning. each scheme.
\end{abstract}

Key Word: contextual approach, motivation, activity, learning achievements, motivator facilitators 
Jurnal PINUS: Jurnal Penelitian Inovasi Pembelajaran, 6 (1), 2020, Mochamad Muchson

\section{PENDAHULUAN}

Salah satu faktor yang menyebabkan sulitnya mahasiswa memahami suatu materi mata kuliah adalah dosen dalam menyampaikan materi mata kuliah cenderung teks book, artinya apa yang ada di buku ditransfer langsung kepada mahasiswa. Padahal materi mata kuliah banyak yang bersifat abstrak dan pengetahuan mahasiswa belum sampai menjangkau kearah materi mata kuliah tersebut. Sehingga mahasiswa meraba-raba dalam memahami suatu materi mata kuliah tersebut dan memerlukan waktu yang lama untuk beradaptasi terhadap substansi bahkan aplikasi dari materi mata kuliah tersebut. Misalnya materi tentang definisi pembangunan ekonomi, Pembangunan ekonomi didefinisikan sebagai setiap kegiatan yang dilakukan suatu negara dalam rangka mengembangkan kegiatan ekonomi dan taraf hidup masyarakatnya. Pembangunan ekonomi adalah suatu proses yang menyebabkan kenaikan pendapatan riil perkapita penduduk suatu negara dalam jangka panjang yang disertai oleh perbaikan sistem kelembagaan.

Apabila dosen hanya mentransfer saja apa yang ada di buku tanpa diberi contoh yang nyata maka mahasiswa kesulitan memahami materi tersebut. Dosen harus mengupas tuntas materi tersebut dengan memberi ilustrasi atau contoh yang nyata. Misalnya ekonomi adalah setiap usaha yang menghasilkan uang, membangun ekonomi berarti membangun usaha yang menghasilkan uang misalnya buka toko, menjadi petani, peternak, usaha sablon dan lain -lain. Demikian pula negara membangun ekonomi berarti mengembangkan kegiatan ekonomi seperti mengembangkan usaha mikro, usaha kecil, usaha menengah, usaha besar atau mengembangkan Badan Usaha Milik Negara, memberi insentif Badan Usaha Milik Swasta, semua itu ditujukan meningkatkan taraf hidup masyarakatnya agar lebih sejahtera. Tolak ukur pembangunan ekonomi adalah pendapatan riil perkapita, semakin tinggi pendapatan riil perkapita suatu negara maka rakyatnya semakin sejatera. Dosen kemudian memaparkan tabel pendapatan riil perkapita antar negara untuk diperbandingkan. Pendapatan riil perkapita adalah pendapatan nasional dibagi dengan jumlah penduduk. Pendapatan nasional adalah jumlah barang dan jasa yang dihasilkan oleh perekonomian suatu negara. Pendapatan nasional dihitung salah satunya dengan metode pengeluaran yaitu $\mathrm{Y}=\mathrm{C}+\mathrm{I}+\mathrm{G}+$ $(\mathrm{X}-\mathrm{M})$. Pembanguna ekonomi tidak semata-mata dilihat dari kenaikan pendapatan riil perkapita tapi juga disertai stabilitas keamanan, stabilitas politik, stabilitas sosial (misalnya tidak ada demo) dan lain-lain.

Di bawah ini disajikan tabel perbandingan hasil tes sebelum dosen memberikan contoh dan sesudah memberi contoh dalam menjelaskan materi.

Tabel hasil tes sebelum dosen memberi contoh dan sesudah memberi contoh dalam menjelaskan materi.

\begin{tabular}{llll}
\hline No. & $\begin{array}{l}\text { Nama } \\
\text { Mahasiswa }\end{array}$ & $\begin{array}{l}\text { Hasil tes } \\
\text { sebelum }\end{array}$ & $\begin{array}{l}\text { Hasil tes } \\
\text { sesudah }\end{array}$ \\
\hline
\end{tabular}


Jurnal PINUS: Jurnal Penelitian Inovasi Pembelajaran, 6 (1), 2020, Mochamad Muchson

\begin{tabular}{|c|c|c|c|}
\hline & & $\begin{array}{l}\text { diberi } \\
\text { contoh }\end{array}$ & $\begin{array}{l}\text { diberi } \\
\text { contoh }\end{array}$ \\
\hline 1 & $\begin{array}{ll}\text { Kinanti } & \text { Tri } \\
\text { Wardani } & \end{array}$ & 65 & 95 \\
\hline 2 & $\begin{array}{ll}\text { Ririn } & \text { Eka } \\
\text { Fariana } & \end{array}$ & 50 & 90 \\
\hline 3 & $\begin{array}{l}\text { Khusnul } \\
\text { Khotimah }\end{array}$ & 55 & 85 \\
\hline 4 & $\begin{array}{l}\text { Devita } \\
\text { Anggara Putri }\end{array}$ & 45 & 80 \\
\hline 5 & Iis Sudarsono & 60 & 90 \\
\hline 6 & Siti Hariyanti & 70 & 100 \\
\hline 7 & Ita Rosiana & 40 & 80 \\
\hline 8 & $\begin{array}{l}\text { Imelda } \\
\text { Donasari }\end{array}$ & 55 & 85 \\
\hline 9 & Meliza Rini & 65 & 95 \\
\hline 10 & Afi Nurlaili & 55 & 85 \\
\hline 11 & $\begin{array}{l}\text { Pipit } \\
\text { Ramadhani }\end{array}$ & 35 & 80 \\
\hline 12 & Devita Dwi & 40 & 80 \\
\hline
\end{tabular}

Sumber data: Hasil tes harian

Salah satu kemampuan dasar yang dimiliki oleh dosen adalah bagaimana dalam proses belajar mengajar mampu memberikan contoh atau ilustrasi terhadap materi yang disampaikan. Dengan contoh-contoh yang nyata atau ilustrasi, mahasiswa akan lebih mudah memahami suatu materi mata kuliah apalagi contoh-contoh atau ilustrasi tersebut dekat dengan peristiwa atau kehidupan sehari-hari mahasiswa. Materi mata kuliah yang abstrak dijelaskan dengan contoh atau ilustrasi memberi dampak mahasiswa dapat menarik benang merah antara kajian teori dengan pemahaman mahasiswa sehingga memudahkan mahasiswa memahami substansi bahkan aplikasi dari materi pelajaran tersebut.

Pemberian contoh atau ilustrasi dalam menjelaskan suatu materi mata kuliah sekarang dikenal dengan pendekatan kontekstual (Contexstual Teaching and Learning). Pendekatan kontekstual merupakan konsep pembelajaran yang menekankan keterkaitan materi mata kuliah dengan kehidupan nyata mahasiswa. Dengan pendekatan kontekstual diharapkan mahasiswa dapat lebih cepat memahami suatu materi mata kuliah yang pada gilirannya dapat membentuk suatu kompetensi. Kompetensi yang diperoleh dari hasil pembelajaran diharapkan dapat diaplikasikan dalam kehidupan seharihari. Melalui pendekatan kontekstual diharapkan mahasiswa dapat meningkatkan aktivitas, kreativitas dan motivasi dalam pembelajaran karena mahasiswa memperoleh makna yang mendalam terhadap suatu materi mata kuliah (Johnson, 2009).

Pendekatan

kontekstual memungkinkan proses belajar yang kreatif dan menyenangkan, karena pembelajaran dilakukan dengan memperhatikan pengalaman belajar mahasiswa, sehingga mahasiswa dapat menerapkan apa yang dipelajarinya. Pembelajaran kontekstual mendorong mahasiswa memahami hakekat, makna, dan manfaat belajar, sehingga memungkinkan mahasiswa meningkatkan motivasi dalam pembelajaran. Kondisi tersebut terwujud, ketika mahasiswa menyadari tentang apa yang mereka perlukan dalam kehidupan,dan bagaimana cara menggapainya.

Dalam pembelajaran kontekstual tugas dosen adalah memberikan kemudahan belajar mahasiswa, dengan menyediakan berbagai sarana dan sumber belajar yang memadai. Dosen bukan hanya menyampaikan materi mata kuliah berupa hafalan, tetapi mengatur 
Jurnal PINUS: Jurnal Penelitian Inovasi Pembelajaran, 6 (1), 2020, Mochamad Muchson

lingkungan dan strategi pembelajaran yang memungkinkan mahasiswa belajar. Lingkungan belajar yang kondusif sangat penting dan sangat menunjang pembelajaran kontekstual, dan tujuan pembelajaran secara keseluruhan.

Berdasarkan uraian diatas penelitian ini mencoba untuk menerapkan pembelajaran dengan pendekatan kontekstual. Pengamatan dilakukan pada mahasiswa terhadap aktivitas, motivasi dan prestasi belajar saat pembelajaran kontekstual dilaksanakan. Berdasarkan latar belakang masalah diatas dirumuskan suatu masalah penelitian yaitu: "Bagaimana upaya peningkatan prestasi belajar pada mata kuliah ekonomi pembangunan melalui pembelajaran kontekstual (Contextual teaching and learning) pada mahasiswa tingkat II Prodi Pendidikan Ekonomi semester genap Tahun Akademik 2018/2019?

\section{METODE PENELITIAN}

Penelitian ini menggunakan Penelitian Tindakan Kelas (PTK) model kolaboratif. Model kolaboratif ini digunakan karena peneliti memerlukan bantuan untuk melakukan observasi pada mahasiswa saat proses belajar mengajar di kelas (Kemmis dan McTaggart, 1988).

Penelitian dilaksanakan di Program Studi Pendidikan Ekonomi semester genap Tahun Akademik 2018/2019. Sedangkan mahasiswa yang digunakan sebegai sasaran penelitian adalah mahaiswa tingkat II (angkatan 2017/2018).

Instrumen pengumpulan data menggunakan 2 macam instrumen yaitu: 1) lembar observasi untuk melihat motivasi dan aktivitas mahasiswa selama proses belajar mengajar dengan pendekatan pembelajaran kontekstual. 2) soal-soal tes hasil belajar untuk mengukur prestasi belajar mahasiswa setelah pembelajaran kontekstual berakhir. Teknik pelaksanaan pengumpulan data untuk melihat motivasi dan aktivitas pembelajaran kontekstual dengan melakukan observasi pada saat proses belajar mengajar satu kompetensi dasar yaitu sebanyak 3x pertemuan (3 siklus). Sedangkan untuk melihat prestasi belajar dilakukan dengan melakukan tes pada setiap akhir siklus.

Berikut ini kisi-kisi lembar observasi motivasi dan aktivitas pembelajaran kontekstual.

Tabel 3.1 Kisi-kisi lembar observasi motivasi dan aktivitas pembelajaran

\begin{tabular}{cll}
\multicolumn{3}{c}{ kontekstual } \\
\hline No. & INDIKATOR SKOR JUMLAH \\
\hline 1. & $\begin{array}{l}\text { Motivasi dalam } \\
\text { PBM }\end{array}$ \\
\hline 2. & $\begin{array}{l}\text { Dapat } \\
\text { menghubungkan } \\
\text { dng lingkungan }\end{array}$ \\
\hline 3. & $\begin{array}{l}\text { Dapat memahami } \\
\text { makna bahan ajar }\end{array}$ \\
\hline 4. & $\begin{array}{l}\text { Aktivitas dalam } \\
\text { PBM }\end{array}$ \\
\hline 5. & Belajar Mandiri \\
\hline 6. & Belajar kritis dan \\
& kreatif \\
\hline 7. & Kemampuan \\
& bertanya \\
\hline 8. & Kemampuan \\
& menemukan \\
\hline 9. & Kerja sama \\
\hline 10. & Membantu \\
& $\begin{array}{l}\text { Masalah } \\
\text { hidupnya }\end{array}$ \\
\hline
\end{tabular}

Sumber: Nurhadi dan Senduk, Agus Gerrad. (2003) 
Jurnal PINUS: Jurnal Penelitian Inovasi Pembelajaran, 6 (1), 2020, Mochamad Muchson

Cara scoring indikator motivasi dn aktivitas pembelajaran kontekstual adalah:

1. Memberikan skor $1=$ motivasi dan aktivitas PBM kurang sekali

2. Memberikan skor $2=$ motivasi dan aktivitas PBM kurang

3. Memberikan skor $3=$ motivasi dan aktivitas PBM cukup

4. Memberikan skor $4=$ motivasi dan aktivitas PBM baik

5. Memberikan skor $5=$ motivasi dan aktivitas PBM baik sekali

6. Menjumlahkan masing-masing skor tersebut di kolom jumlah, dimana jumlah terendah 10 dan jumlah tertinggi 50 .

Sedangkan untuk melihat prestasi belajar setelah pembelajaran kontekstual dilakukan dengan melakukan test setelah pembelajaran kontekstual berakhir yaitu diakhir setiap siklus (3 siklus). Test hasil belajar ini dimaksudkan untuk memperoleh gambaran mengenai hasil belajar mahasiswa setelah pembelajaran kontekstual berakhir. Bentuk testnya adalah pilihan ganda dan uraian.

Cara pemberian skor pada test di akhir setiap siklus adalah berpedoman pada bobot masing-masing jenis soal. Untuk jenis pilihan ganda bobot soalnya adalah 10 dengan skor masing-masing soal 1 dengan jumlah soal 10. Untuk jenis soal uraian bobot soalnya adalah 40 dengan skor masing-masing soal 8 dengan jumlah soal 5, total skor dari kedua jenis soal tersebut adalah 50 .

\section{Analisis data dan Kriteria Refleksi}

Data hasil observasi motivasi dan aktivitas mahasiswa selama mengikuti proses belajar mengajar dengan pendekatan kontekstual dan nilai hasil test akan dianalisis bersama-sama guna menentukan apakah pembelajaran kontekstual dapat meningkatkan prestasi belajar mahasiswa. Selanjutnya berdasar data-data yang terkumpul setelah dilakukan tabulasi dan skoring, akan ditafsirkan menggunakan kajian teori yang telah dikembangkan, serta menggunakan pengalaman empiris yang sering diamati dosen dalam kehidupan sehari-hari mahasiswa.

Kriteria dan refleksi data-data motivasi dan aktivitas pembelajaran kontekstual akan digunakan kriteria yaitu:

1. Skor $10-20$ (kurang) artinya mahasiswa kurang ada motivasi dan aktivitas PBM

2. Skor 21 - 30 (cukup) artinya mahasiswa cukup ada motivasi dan aktivitas PBM

3. Skor $31-40$ (baik) artinya motivasi dan aktivitas PBM mahasiswa baik

4. Skor 41 - 50 (baik sekali) artinya motivasi dan aktivitas PBM mahasiswa baik sekali

Sedangkan data test untuk disetiap akhir siklus setelah dilakukan koreksi dan skoring akan dianalisis berdasarkan kriteria ketuntasan belajar (mastery learning), yaitu:

1. Untuk hasil test $10-20 \quad$ Prestasi belajar kurang

2. Untuk hasil test 21 - 30 Prestasi belajar cukup

3. Untuk hasil test 31 - 40 Prestasi belajar baik

4. Untuk hasil test 41 - 50 Prestasi belajar baik sekali

1. Untuk ketuntasan individual adalah diatas 31 taraf penguasaan materi, dan 
Jurnal PINUS: Jurnal Penelitian Inovasi Pembelajaran, 6 (1), 2020, Mochamad Muchson

2. Untuk ketuntasan kelompok (kelas) adalah $85 \%$ dari jumlah mahasiswa telah mencapai 31 taraf penguasaan materi yang diberikan.

Rumus statistik deskriptif yang digunakan untuk menganalisis data adalah:

Skor perolehan

$$
\text { Nilai }={ }_{\text {Skor maksimal }} \times 100
$$

(M. Muchson, 2015)

\section{LAPORAN HASIL PENELITIAN}

\section{Persiapan Proses Pembelajaran}

Sebelum melakukan penelitian, peneliti membuat tahapan tindakan sebagai berikut:

1. Memberitahukan rencana penelitian tindakan kelas kepada ketua program studi, sekaligus untuk memperoleh saran dan masukan yang mungkin berguna saat pelaksanaan.

2. Meminta persetujuan salah seorang rekan dosen, sekaligus meminta kesediaan untuk berdiskusi dan membantu pelaksanaan penelitian sebagai kolaborator (observer).

3. Penyusunan perangkat persiapan pembelajaran yang terdiri dari:

a. Kompetensi dasar: Mahasiswa mempunyai kemampuan memahami pembangunan ekonomi dengan indikator:

1) Mendeskripsikan pendapatan nasional pendekatan produksi

2) Mendiskripsikan pendapatan nasional pendekatan pendapatan
3) Mendiskripsikan pendapatan nasional pendekatan pengeluaran

b. Analisis materi pembelajaran. Maksudnya menganalisis materi mata kuliah disesuaikan dengan strategi pembelajaran kontekstual
c. Penyusunan perangkat persiapan mengajar.

d. Penyusunan lembar kerja mahasiswa.
e. Pengadaan alat bantu pengajaran.

4. Membuat instrumen-instrumen yang digunakan, yaitu:

a. lembar observasi motivasi dan aktivitas proses belajar mengajar dengan pendekatan pembelajaran kontekstual
b. lembar soal test yang digunakan setelah pembelajaran disetiap siklus selesai yaitu 3 siklus.

5. Mempersiapkan beberapa lembar daftar absensi dan daftar nilai tingkat II yang akan dijadikan sasaran penelitian.

2. Siklus pertama: Pelaksanaan Pembelajaran kontekstual dengan indikator pendapatan nasional pendekatan produksi. Pelaksanaan Pembelajaran kontekstual dengan indikator pendapatan nasional pendekatan produksi meliputi 4 tahapan yang akan dilalui sebagai berikut:

\section{Persiapan (Planning)}

a. Identifikasi kompetensi dasar dan indikator

Kompetensi dasar: Mahasiswa mempunyai kemampuan 
Jurnal PINUS: Jurnal Penelitian Inovasi Pembelajaran, 6 (1), 2020, Mochamad Muchson

$\begin{array}{lr}\text { memahami } & \text { pembangunan } \\ \text { ekonomi. } & \text { Indikator: } \\ \text { pendapatan } & \text { nasional } \\ \text { pendekatan produksi. } & \end{array}$

b. Analisis materi pembelajaran

Analisis materi pembelajaran disini maksudnya adalah menganalisis materi pembelajaran disesuaikan dengan strategi pembelajaran kontekstual.

c. Penyusunan Rencana Pembelajaran

d. Penyusunan lembar kerja mahasiswa berupa soal-soal test

e. Pengadaan media atau alat bantu pengajaran berupa gambar ilustrasi pendapatan nasional.

2. Pelaksanaan (Acting)

Dosen membuka pelajaran, memberikan apersepsi kemudian masuk pada kegiatan inti. Pada kegiatan inti ini dosen menjelaskan materi mata kuliah dengan pendekatan kontekstual yaitu menjelaskan pengertian dan konsep penghitungan pendapatan nasional. Menurut pendekatan produksi pendapatan nasional adalah penjumlahan nilai tambah dari setiap barang dan jasa yang dihasilkan oleh suatu negara dalam periode tertentu. Penjelasan disertai dengan contoh-contoh yang kontekstual yang ada dalam kehidupan sehari-hari misalnya contoh barang, contoh jasa yang dihasilkan perekonomian negara, contoh nilai tambah. Setelah selesai menjelaskan dosen memberi tugas kelompok.

Tugas anda sekarang adalah kelas dibagi menjadi dua kelompok besar, kelompok A dan kelompok B. kemudian kelompok A dibagi menjadi A1 dan A2. Demikian pula kelompok B dibagi menjadi Kelompok B1 dan B2. Kelompok A1 dan B1 mengamati dan mencatat barang yang ada disekitar lingkungannya. Demikian pula kelompok A2 dan B2 mengamati dan mencatat jasa yang ada disekitar lingkungannya. Setelah selesai masing-masing kelompok A dan B akan mempresentasikan hasil pengamatannya. Kelompok A1 akan berhadapan dengan B1 dan kelompok A2 akan berhadapan dengan kelompok B2. Setelah presentasi selesai masing-masing kelompok disuruh membuat kesimpulan tentang hasil presentasi.

Setelah pertemuan berakhir dosen menyimpulkan pokok-pokok materi dan menyampaikan materi yang akan dibahas pertemuan berikutnya.

3. Pengamatan (Observing)

Dosen observer melakukan pengamatan pada aktivitas mahasiswa pada saat proses belajar mengajar di kelas. Seperti disampaikan dimuka bahwa observasi ini untuk mengetahui apakah proses pembelajaran kontekstual dapat meningkatkan motivasi dan aktivitas belajar anak. Pada akhir pertemuan diadakan test untuk melihat apakah pembelajaran 
Jurnal PINUS: Jurnal Penelitian Inovasi Pembelajaran, 6 (1), 2020, Mochamad Muchson

kontekstual dapat meningkatkan prestasi belajar mahasiswa.

Berikut ini disajikan hasil observasi motivasi dan aktivitas mahasiswa dalam PBM kontekstual siklus pertama.

Tabel 4.1: Hasil observasi motivasi dan aktivitas mahasiswa dalam PBM kontekstual siklus pertama. Nama mahasiswa: IIS SUDARSONO

\begin{tabular}{clcc}
\hline No & \multicolumn{1}{c}{ Indikator } & Skor & \multicolumn{1}{c}{ Jumlah } \\
\hline 1. & $\begin{array}{l}\text { Motivasi dalam } \\
\text { PBM }\end{array}$ & 2 & 25 nilai 50 \\
\hline 2. & $\begin{array}{l}\text { Dapat } \\
\text { menghubungkan } \\
\text { dng lingkungan }\end{array}$ & \\
\hline 3. & $\begin{array}{l}\text { Dapat } \\
\text { memahami } \\
\text { makna bahan ajar }\end{array}$ & 3 \\
\hline 4. & $\begin{array}{l}\text { Aktivitas dalam } \\
\text { PBM }\end{array}$ \\
\hline 5. & Belajar Mandiri & 3 \\
\hline 6. & $\begin{array}{l}\text { Belajar kritis dan } \\
\text { kreatif }\end{array}$ & 3 \\
\hline 7. & $\begin{array}{l}\text { Kemampuan } \\
\text { bertanya }\end{array}$ & 3 \\
\hline 8. & $\begin{array}{l}\text { Kemampuan } \\
\text { menemukan }\end{array}$ & 2 \\
\hline 9. & Kerja sama & 3 \\
\hline 10. & $\begin{array}{l}\text { Membantu } \\
\text { Masalah } \\
\text { hidupnya }\end{array}$ & 2 \\
\hline
\end{tabular}

Cara scoring indikator motivasi $\mathrm{dn}$ aktivitas pembelajaran kontekstual adalah:

1. Memberikan skor $1=$ motivasi dan aktivitas PBM kurang sekali

2. Memberikan skor $2=$ motivasi dan aktivitas PBM kurang

3. Memberikan skor $3=$ motivasi dan aktivitas PBM cukup

4. Memberikan skor $4=$ motivasi dan aktivitas PBM baik
5. Memberikan skor $5=$ motivasi dan aktivitas PBM baik sekali

6. Menjumlahkan masing-masing skor tersebut di kolom jumlah, dimana jumlah terendah 10 dan jumlah tertinggi 50 .

Dari hasil analisa data observasi motivasi dan aktivitas belajar dengan menggunakan pendekatan kontekstual siklus pertama dari kedua belas sampel penelitian menunjukkan semua mempunyai skor antara 21 - 30 berarti sesuai dengan pedoman scoring skala 100 motivasi dan aktivitas mahasiswa dalam pembelajaran kontekstual berkategori cukup.

Sedangkan data test untuk disetiap akhir siklus setelah dilakukan koreksi dan scoring akan dianalisis berdasarkan kriteria ketuntasan belajar (mastery learning), yaitu:

1. Untuk hasil test $10-20 \quad$ Prestasi belajar kurang

2. Untuk hasil test 21 - 30 Prestasi belajar cukup

3. Untuk hasil test $31-40 \quad$ Prestasi belajar baik

4. Untuk hasil test 41 - 50 Prestasi belajar baik sekali

Rumus statistik deskriptif yang digunakan untuk menganalisis data adalah:

$$
\text { Nilai }=\frac{\text { Skor perolehan }}{\text { Skor maksimal }} \times 100
$$


Jurnal PINUS: Jurnal Penelitian Inovasi Pembelajaran, 6 (1), 2020, Mochamad Muchson

Tabel 4.2 Nilai test materi mata kuliah siklus pertama

\begin{tabular}{|c|c|c|c|c|}
\hline No & $\begin{array}{c}\text { Nama } \\
\text { Mahasiswa }\end{array}$ & $\begin{array}{c}\text { Nilai } \\
\text { Test } \\
\text { Pilihan } \\
\text { Ganda }\end{array}$ & $\begin{array}{c}\text { Nilai } \\
\text { Test } \\
\text { Uraian }\end{array}$ & Jumlah \\
\hline 1 & $\begin{array}{l}\text { Kinanti Tri } \\
\text { Wardani }\end{array}$ & 6 & 25 & $\begin{array}{c}31 \text { nilai } \\
62\end{array}$ \\
\hline 2 & $\begin{array}{l}\text { Ririn Eka } \\
\text { Fariana }\end{array}$ & 5 & 30 & $\begin{array}{c}35 \text { nilai } \\
70\end{array}$ \\
\hline 3 & $\begin{array}{l}\text { Khusnul } \\
\text { Khotimah }\end{array}$ & 7 & 20 & $\begin{array}{c}27 \text { nilai } \\
54\end{array}$ \\
\hline 4 & $\begin{array}{l}\text { Devita } \\
\text { Anggara } \\
\text { Putri }\end{array}$ & 4 & 30 & $\begin{array}{c}34 \text { nilai } \\
68\end{array}$ \\
\hline 5 & $\begin{array}{l}\text { Iis } \\
\text { Sudarsono }\end{array}$ & 6 & 25 & $\begin{array}{c}31 \text { nilai } \\
62\end{array}$ \\
\hline 6 & $\begin{array}{l}\text { Siti } \\
\text { Hariyanti }\end{array}$ & 8 & 17 & $\begin{array}{c}25 \text { nilai } \\
50\end{array}$ \\
\hline 7 & Ita Rosiana & 7 & 25 & $\begin{array}{c}32 \text { nilai } \\
64\end{array}$ \\
\hline 8 & $\begin{array}{l}\text { Imelda } \\
\text { Donasari }\end{array}$ & 5 & 23 & $\begin{array}{c}28 \text { nilai } \\
56\end{array}$ \\
\hline 9 & Meliza Rini & 8 & 28 & $\begin{array}{c}36 \text { nilai } \\
72\end{array}$ \\
\hline 10 & Afi Nurlaili & 6 & 23 & $\begin{array}{c}29 \text { nilai } \\
58\end{array}$ \\
\hline 11 & $\begin{array}{l}\text { Pipit } \\
\text { Ramadhani }\end{array}$ & 10 & 28 & $\begin{array}{c}38 \text { nilai } \\
76\end{array}$ \\
\hline 12 & Devita Dwi & 7 & 17 & $\begin{array}{c}24 \text { nilai } \\
48\end{array}$ \\
\hline
\end{tabular}

Dari hasil analisa data hasil test materi mata kuliah siklus pertama dengan metode kontekstual dihasilkan data sebagai berikut: (KKM 61)

1. Ada 5 mahasiswa yang memperoleh nilai antara 21 - 30 (dibawah 60) sehingga $\quad 40 \% \quad$ mahasiswa berkategori mempunyai nilai cukup.

2. Ada 7 mahasiswa yang memperoleh nilai antara $31-40 \quad(61-80)$ sehingga $\quad 60 \%$ mahasiswa berkategori mempunyai nilai baik.

3. Dilihat dari ketuntasan proses belajar mengajar secara individu $60 \%$ mahasiswa sudah tuntas dalam memahami materi mata kuliah. Tapi dilihat dari ketuntasan kelas karena masih 60\% mahasiswa yang mempunyai nilai diatas 31 belum $85 \%$, maka secara keseluruhan kelas belum menampakkan ketuntasan belajar.

5. Refleksi/pembahasan siklus pertama Dilihat dari hasil analisa data observasi motivasi dan aktivitas belajar dengan metode kontekstual siklus pertama dihasilkan kesimpulan bahwa motivasi dan aktivitas belajar mahasiswa berkategori cukup. Sedang dilihat dari hasil test materi mata kuliah secara individu 40\% mahasiswa berkategori cukup dan $60 \%$ mahasiswa berkategori baik. Dilihat dari tingkat ketuntasan belajar ternyata secara individu $60 \%$ mahasiswa sudah tuntas belajarnya dan apabila dilihat dari ketuntasan kelas ternyata belum menampakkan ketuntasan belajar. Mengapa hal ini bisa terjadi, ada beberapa sebab:

1. Motivasi dan aktivitas mahasiswa dalam pembelajaran pendekatan kontekstual siklus pertama berkategori cukup karena mahasiswa belum terbiasa dengan pembelajaran kontekstual. Mahasiswa terbiasa dengan metode ceramah dimana dosen langsung menerangkan materi mata kuliah. Dalam pembelajaran kontekstual ini mahasiswa masih banyak yang diam menunggu perintah dari dosen untuk melaksanakan suatu aktivitas. 
Jurnal PINUS: Jurnal Penelitian Inovasi Pembelajaran, 6 (1), 2020, Mochamad Muchson

2. Hasil test menunjukkan $40 \%$ mahasiswa mempunyai nilai yang cukup dan $60 \%$ mahasiswa mempunyai nilai baik. Hal ini juga disebabkan mahasiswa sudah terbiasa dengan metode ceramah dimana dosen langsung menerangkan materi mata kuliah dan mahasiswa menerima materi mata kuliah tersebut dalam pembelajaran kontekstual pengetahuan dapat dicari melalui keterlibatan mahasiswa dalam pembelajaran. Pada siklus pertama ini motivasi dan aktivitas mahasiswa dalam pembelajaran masih cukup sehingga pemahaman materipun juga masih cukup yang mengakibatkan nilai testnya masih berkisar antara $40 \%$ cukup dan $60 \%$ baik.

3. Agar motivasi, aktivitas dan nilai testnya tinggi dosen mencoba melaksanakan pembelajaran kontekstual siklus kedua dengan lebih menekankan mahasiswa untuk terlibat aktif dalam pembelajaran.

3. Siklus kedua: Pelaksanaan Pembelajaran kontekstual indikator: pendapatan nasional pendekatan pendapatan.Pelaksanaan

Pembelajaran kontekstual dengan indikator pendapatan nasional pendekatan pendapatan meliputi 4 tahapan yang akan dilalui sebagai berikut:

1. Persiapan (planning)

a. Identifikasi standart kompetensi dan kompetensi dasar
Kompetensi dasar: Mahasiswa mempunyai kemampuan memahami pembangunan ekonomi. Indikator: Mendiskripsikan pendapatan nasional pendekatan pendapatan.

b. Analisis materi pembelajaran Analisis materi pembelajaran disini maksudnya adalah menganalisis materi pembelajaran disesuaikan dengan strategi pembelajaran kontekstual.

c. Penyusunan Rencana Pembelajaran

d. Penyusunan lembar kerja mahasiswa berupa soal-soal test

e. Pengadaan media atau alat bantu pengajaran berupa gambar tentang pendapatan nasional.

3. Pelaksanaan (Acting)

Dosen membuka pelajaran, memberikan apersepsi dan dosen memberitahu kepada mahasiswa mengenai proses pembelajaran yang dilakukan yaitu pembelajaran kontekstual.

Setelah membuka pelajaran dosen masuk pada kegiatan inti yaitu menyampaikan materi mata kuliah. Seperti telah disampaikan di atas indikatornya adalah mendiskripsikan pendapatan nasional pendekatan pendapatan. Pada pertemuan yang lalu kita telah membahas masalah pendapatan nasional pendekatan produksi beserta contohnya. Coba siapa yang masih ingat? Kemudian ada 
Jurnal PINUS: Jurnal Penelitian Inovasi Pembelajaran, 6 (1), 2020, Mochamad Muchson

beberapa mahasiswa yang mengacungkan jarinya. Dari jawaban-jawaban mahasiswa tersebut dosen membenarkan kemudian melanjutkan pada pembahasan materi pendapatan nasional pendekatan pendapatan. Pendapatan nasional pendekatan pendapatan adalah pendekatan pendapatan nasional yang menghitung jumlah pendapatan yang diterima oleh pemilik faktor produksi yang digunakan untuk memproduksi barang dan jasa suatu negara dalam satu periode. Misalnya pemilik tanah mendapat sewa, tenaga kerja mendapat upah, perusahaan mendapat laba dan lainlain. Penjelasan disertai contohcontoh yang ada dalam kehidupan sehari-hari siswa. Setelah menjelaskan materi dosen membagi kelas menjadi dua kelompok A dan $\mathrm{B}$, kelompok A1 dan B1 mengamati dan mencatat contoh pendapatan nasional pendekatan produksi. Kelompok A2 dan B2 mengamati dan mencatat pendapatan nasional pendekatan pendapatan. Hasil pengamatan akan dipresentasikan dimana kelompok A akan berhadapan dengan kelompok B.

Setelah pertemuan berakhir dosen menyuruh mahasiswa untuk menyimpulkan pengertian pendapatan nasional pendekatan pendapatan.

4. Pengamatan (Observing)

Dosen observer melakukan pengamatan pada aktivitas mahasiswa pada saat proses belajar mengajar di kelas. Seperti disampaikan dimuka bahwa observasi ini untuk mengetahui apakah proses pembelajaran kontekstual dapat meningkatkan motivasi dan aktivitas belajar anak karena materi bahan ajar dan aktivitas belajar dikaitkan dengan kehidupan mahasiswa. Setelah siklus kedua selesai akan diadakan test/ujian yaitu untuk melihat apakah pembelajaran kontekstual akan dapat meningkatkan prestasi belajar mahasiswa.

Berikut ini disajikan hasil observasi motivasi dan aktivitas mahasiswa dalam PBM kontekstual siklus kedua.

Tabel 4.3: Hasil observasi motivasi dan aktivitas mahasiswa dalam PBM

kontekstual siklus kedua

Nama mahasiswa: IIS SUDARSONO

\begin{tabular}{clcc}
\hline No & INDIKATOR & SKOR & JUMLAH \\
\hline 1. & $\begin{array}{l}\text { Motivasi dalam } \\
\text { PBM }\end{array}$ & 4 & 37 nilai 74 \\
\hline 2. & $\begin{array}{l}\text { Dapat } \\
\text { menghubungkan } \\
\text { dng lingkungan }\end{array}$ & 4 \\
\hline 3. & $\begin{array}{l}\text { Dapat memahami } \\
\text { makna bahan ajar }\end{array}$ & 4 \\
\hline 4. & $\begin{array}{l}\text { Aktivitas dalam } \\
\text { PBM }\end{array}$ \\
\hline 5. & Belajar Mandiri & 3 \\
\hline 6. & $\begin{array}{l}\text { Belajar kritis dan } \\
\text { kreatif }\end{array}$ & 3 \\
\hline 7. & $\begin{array}{l}\text { Kemampuan } \\
\text { bertanya }\end{array}$ & 4 \\
\hline 8. & $\begin{array}{l}\text { Kemampuan } \\
\text { menemukan }\end{array}$ & 3 \\
\hline 9. & Kerja sama \\
\hline 10. & $\begin{array}{l}\text { Membantu } \\
\text { Masalah } \\
\text { hidupnya }\end{array}$ \\
\hline
\end{tabular}


Jurnal PINUS: Jurnal Penelitian Inovasi Pembelajaran, 6 (1), 2020, Mochamad Muchson

Dari hasil analisa data observasi motivasi dan aktivitas belajar dengan menggunakan metode kontekstual siklus kedua dari kedua belas sampel penelitian menunjukkan lima mempunyai skor antara $31-40$ berarti sesuai dengan pedoman scoring, $40 \%$ motivasi dan aktivitas mahasiswa dalam pembelajaran kontekstual siklus kedua berkategori baik dan 7 mempunyai skor antara $41-50$ berarti sesuai dengan pedoman scoring, $60 \%$ motivasi dan aktivitas mahasiswa dalam pembelajaran kontekstual siklus kedua berkategori baik sekali.

Tabel 4.4 Nilai test materi mata kuliah dengan metode kontekstual siklus kedua

\begin{tabular}{|c|c|c|c|c|}
\hline No & $\begin{array}{c}\text { Nama } \\
\text { Mahasiswa }\end{array}$ & $\begin{array}{c}\text { Nilai } \\
\text { Test } \\
\text { Pilihan } \\
\text { Ganda }\end{array}$ & $\begin{array}{c}\text { Nilai } \\
\text { Test } \\
\text { Uraian }\end{array}$ & Jumlah \\
\hline 1. & $\begin{array}{l}\text { Kinanti Tri } \\
\text { Wardani }\end{array}$ & 8 & 30 & $\begin{array}{c}38 \text { nilai } \\
76\end{array}$ \\
\hline 2. & $\begin{array}{ll}\text { Ririn } & \text { Eka } \\
\text { Fariana } & \end{array}$ & 9 & 35 & $\begin{array}{c}44 \text { nilai } \\
88\end{array}$ \\
\hline 3. & $\begin{array}{l}\text { Khusnul } \\
\text { Khotimah }\end{array}$ & 8 & 25 & $\begin{array}{c}33 \text { nilai } \\
66\end{array}$ \\
\hline 4. & $\begin{array}{l}\text { Devita } \\
\text { Anggara Putri }\end{array}$ & 6 & 30 & $\begin{array}{c}38 \text { nilai } \\
76\end{array}$ \\
\hline 5. & Iis Sudarsono & 7 & 35 & $\begin{array}{c}42 \text { nilai } \\
84\end{array}$ \\
\hline 6. & Siti Hariyanti & 8 & 24 & $\begin{array}{c}32 \text { nilai } \\
64\end{array}$ \\
\hline 7. & Ita Rosiana & 9 & 37 & $\begin{array}{c}46 \text { nilai } \\
92\end{array}$ \\
\hline 8. & $\begin{array}{l}\text { Imelda } \\
\text { Donasari }\end{array}$ & 7 & 30 & $\begin{array}{c}37 \text { nilai } \\
74\end{array}$ \\
\hline 9. & Meliza Rini & 8 & 37 & $\begin{array}{c}45 \text { nilai } \\
90\end{array}$ \\
\hline 10. & Afi Nurlaili & 6 & 30 & $\begin{array}{c}36 \text { nilai } \\
72\end{array}$ \\
\hline 11. & $\begin{array}{l}\text { Pipit } \\
\text { Ramadhani }\end{array}$ & 10 & 40 & $\begin{array}{c}48 \text { nilai } \\
96\end{array}$ \\
\hline 12. & Devita Dwi & 7 & 27 & $\begin{array}{c}34 \text { nilai } \\
68\end{array}$ \\
\hline
\end{tabular}

Dari hasil analisa data hasil test materi mata kuliah metode kontekstual siklus kedua dihasilkan data sebagai berikut: (KKM 61)

1. Ada 7 mahasiswa yang memperoleh nilai antara $31-40$ sehingga $(61-80) \quad 60 \%$ mahasiswa berkategori mempunyai nilai baik.

2. Ada 5 mahasiswa yang memperoleh nilai antara $41-50$ (81 - 100) sehingga (diatas 81) $40 \%$ mahasiswa berkategori mempunyai nilai baik sekali.

3. Dilihat dari ketuntasan proses belajar mengajar secara individu $100 \%$ mahasiswa sudah tuntas dalam memahami materi mata kuliah. Dilihat dari ketuntasan kelas karena $100 \%$ mahasiswa yang mempunyai nilai diatas 31 , maka secara keseluruhan kelas telah menampakkan ketuntasan belajar.

5. Refleksi/pembahasan siklus kedua

Dilihat dari hasil analisa data observasi dan aktivitas belajar dengan metode kontekstual siklus kedua dihasilkan kesimpulan bahwa motivasi dan aktivitas belajar $60 \%$ mahasiswa berkategori baik dan $40 \%$ mahasiswa berkategori baik sekali. Sedang dilihat dari hasil test materi mata kuliah secara individu $60 \%$ mahasiswa berkategori baik dan 40\% mahasiswa berkategori baik sekali. Dilihat dari tingkat ketuntasan belajar ternyata baik secara individu maupun secara kelas $100 \%$ mahasiswa sudah 
Jurnal PINUS: Jurnal Penelitian Inovasi Pembelajaran, 6 (1), 2020, Mochamad Muchson

tuntas belajarnya. Mengapa hal ini bisa terjadi, ada beberapa sebab:

1. Motivasi dan aktivitas mahasiswa dalam pembelajaran kontekstual siklus kedua berkategori baik dan baik sekali karena dosen memotivasi mahasiswa untuk aktif terlibat dalam pembelajaran. Dosen dengan sengaja mendekati mahasiswa satu persatu untuk memberi pengarahan proses pembelajaran seperti cara mengidentifikasi pendapatan nasional.

2. Nilai test siklus kedua menunjukkan nilai dengan kategori baik dan baik sekali karena mahasiswa sudah mulai terlibat dalam pembelajaran sehingga pemahaman terhadap materi mulai ada peningkatan yang mengakibatkan hasil testnya banyak peningkatan.

3. Walaupun demikian dalam pembelajaran kontekstual siklus ketiga dosen tetap memotivasi mahasiswa untuk terlibat dalam proses pembelajaran. Dalam siklus ketiga ini dosen bertindak sebagai motivator dan fasilitator dan akan membimbing mahasiswa apabila mahasiswa ada kesulitan.

4. Siklus ketiga: Pelaksanaan Pembelajaran kontekstual indikator: mendiskripsikan pendapatan nasioanal pendekatan pengeluaran. Pelaksanaan Pembelajaran kontekstual dengan indikator mendiskripsikan pendapatan nasional pendekatan pengeluaran meliputi 4 tahapan yang akan dilalui sebagai berikut:

1. Persiapan (planning)

a. Identifikasi standart kompetensi dan kompetensi dasar

Kompetensi dasar: Mahasiswa mempunyai kemampuan memahami pembangunan ekonomi. Indikator: mendiskripsikan pendapatan nasional pendekatan pengeluaran.

b. Analisis materi pembelajaran Analisis materi pembelajaran disini maksudnya adalah menganalisis materi pembelajaran disesuaikan dengan strategi pembelajaran kontekstual.

c. Penyusunan Rencana Pembelajaran

d. Penyusunan lembar kerja mahasiswa berupa soal-soal test

e. Pengadaan media atau alat bantu pengajaran berupa gambar pendapatan nasional pendekatan pengeluaran.

3. Pelaksanaan (Acting)

Dosen membuka pelajaran, memberikan apersepsi dan dosen memberitahu kepada mahasiswa mengenai proses pembelajaran yang dilakukan yaitu pembelajaran kontekstual.

Setelah membuka pelajaran dosen masuk pada 
Jurnal PINUS: Jurnal Penelitian Inovasi Pembelajaran, 6 (1), 2020, Mochamad Muchson

\begin{tabular}{|c|c|c|}
\hline $\begin{array}{l}\text { kegiatan } \\
\text { menyampaik }\end{array}$ & $\begin{array}{c}\text { inti } \\
\text { mat }\end{array}$ & $\begin{array}{l}\text { yaitu } \\
\text { mata }\end{array}$ \\
\hline culiah. & Seperti & el \\
\hline sampaikan & & \\
\hline dikatornya & & ne \\
\hline isional & & 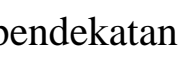 \\
\hline $\begin{array}{l}\text { geluaran. } \\
\text { onal }\end{array}$ & & bend \\
\hline
\end{tabular}

pengeluaran adalah menghitung pendapatan nasional dari jumlah pengeluaran seluruh pelaku ekonomi baik di dalam negeri maupun di luar negeri selama satu periode tertentu. Penjelasan diberi contoh misalnya pengeluaran rumah tangga (C), pengeluaran perusahaan (I), pengeluaran pemerintah $(\mathrm{G})$ dan lain-lain. Setelah dosen menjelaskan kemudian memberi tugas yaitu secara individu mengamati dan mencatat semua pengeluaran seluruh pelaku ekonomi baik di dalam negeri maupun di luar negeri.

\begin{tabular}{lr}
\multicolumn{1}{c}{ Setelah } & pertemuan \\
merakhir dosen & menyuruh \\
mahasiswa & untuk \\
menyimpulkan pengertian dan \\
cara penghitungan & pendapatan \\
nasional & pendekatan \\
pengeluaran. &
\end{tabular}

4. Pengamatan (Observing)

Dosen observer melakukan pengamatan pada aktivitas mahasiswa pada saat proses belajar mengajar di kelas. Seperti disampaikan dimuka bahwa observasi ini untuk mengetahui apakah proses pembelajaran kontekstual dapat meningkatkan motivasi dan

Tabel 4.5: Hasil observasi motivasi dan aktivitas mahasiswa dalam PBM kontekstual siklus ketiga

Nama mahasiswa: IIS SUDARSONO

\begin{tabular}{clcc}
\hline No. & INDIKATOR & SKOR & JUMLAH \\
\hline 1. & $\begin{array}{l}\text { Motivasi dalam } \\
\text { PBM }\end{array}$ & 4 & $\begin{array}{c}44 \text { nilai } \\
88\end{array}$ \\
\hline 2. & $\begin{array}{l}\text { Dapat } \\
\text { menghubungkan } \\
\text { dng lingkungan }\end{array}$ & 4 & \\
\hline 3. & $\begin{array}{l}\text { Dapat } \\
\text { memahami } \\
\text { makna bahan } \\
\text { ajar }\end{array}$ & 5 \\
\hline 4. & $\begin{array}{l}\text { Aktivitas dalam } \\
\text { PBM }\end{array}$ & 4 \\
\hline 5. & Belajar Mandiri & 4 \\
\hline 6. & $\begin{array}{l}\text { Belajar kritis } \\
\text { dan kreatif }\end{array}$ & 5 \\
\hline 7. & $\begin{array}{l}\text { Kemampuan } \\
\text { bertanya }\end{array}$ & 4 \\
\hline 8. & $\begin{array}{l}\text { Kemampuan } \\
\text { menemukan }\end{array}$ \\
\hline 9. & Kerja sama & 4 \\
\hline 10. & $\begin{array}{l}\text { Membantu } \\
\text { Masalah } \\
\text { hidupnya }\end{array}$ & 5 \\
\hline
\end{tabular}

Dari hasil analisa data observasi motivasi dan aktivitas belajar dengan 
Jurnal PINUS: Jurnal Penelitian Inovasi Pembelajaran, 6 (1), 2020, Mochamad Muchson

menggunakan metode kontekstual siklus ketiga dari kedua belas sampel penelitian menunjukkan dua mempunyai skor antara 31 - 40 berarti sesuai dengan pedoman scoring, $20 \%$ motivasi dan aktivitas mahasiswa dalam pembelajaran kontekstual siklus ketiga berkategori baik dan 10 mempunyai skor antara $41-50$ berarti sesuai dengan pedoman scoring, $80 \%$ motivasi dan aktivitas mahasiswa dalam pembelajaran kontekstual siklus ketiga berkategori baik sekali.

Tabel 4.6 Nilai test materi mata kuliah dengan metode kontekstual siklus

\begin{tabular}{|c|c|c|c|c|}
\hline \multicolumn{5}{|c|}{ ketiga } \\
\hline $\begin{array}{c}\text { No } \\
\text {. }\end{array}$ & $\begin{array}{c}\text { Nama } \\
\text { Mahasiswa }\end{array}$ & $\begin{array}{c}\text { Nilai } \\
\text { Test } \\
\text { Pilihan } \\
\text { Ganda }\end{array}$ & $\begin{array}{c}\text { Nilai } \\
\text { Test } \\
\text { Uraian }\end{array}$ & Jumlah \\
\hline 1. & $\begin{array}{l}\text { Kinanti Tri } \\
\text { Wardani }\end{array}$ & 8 & 40 & $\begin{array}{c}48 \\
\text { nilai } \\
96\end{array}$ \\
\hline 2. & $\begin{array}{l}\text { Ririn Eka } \\
\text { Fariana }\end{array}$ & 7 & 35 & $\begin{array}{c}42 \\
\text { nilai } \\
84\end{array}$ \\
\hline 3. & $\begin{array}{l}\text { Khusnul } \\
\text { Khotimah }\end{array}$ & 9 & 35 & $\begin{array}{c}44 \\
\text { nilai } \\
88\end{array}$ \\
\hline 4. & $\begin{array}{l}\text { Devita } \\
\text { Anggara } \\
\text { Putri }\end{array}$ & 8 & 40 & $\begin{array}{c}48 \\
\text { nilai } \\
96\end{array}$ \\
\hline 5. & $\begin{array}{l}\text { Iis } \\
\text { Sudarsono }\end{array}$ & 10 & 31 & $\begin{array}{c}41 \\
\text { nilai } \\
80\end{array}$ \\
\hline 6. & $\begin{array}{l}\text { Siti } \\
\text { Hariyanti }\end{array}$ & 8 & 29 & $\begin{array}{c}37 \\
\text { nilai } \\
74\end{array}$ \\
\hline 7. & Ita Rosiana & 9 & 37 & $\begin{array}{c}46 \\
\text { nilai } \\
92\end{array}$ \\
\hline 8. & $\begin{array}{l}\text { Imelda } \\
\text { Donasari }\end{array}$ & 7 & 38 & $\begin{array}{c}45 \\
\text { nilai } \\
90\end{array}$ \\
\hline 9. & $\begin{array}{l}\text { Meliza } \\
\text { Rini }\end{array}$ & 9 & 26 & $\begin{array}{c}35 \\
\text { nilai } \\
70\end{array}$ \\
\hline
\end{tabular}

\begin{tabular}{llccc}
\hline 10. & Afi & 8 & 35 & 43 \\
& Nurlaili & & & $\begin{array}{c}\text { nilai } \\
86\end{array}$ \\
\hline 11. & Pipit & 10 & 38 & 48 \\
& Ramadhan & & & nilai \\
& i & & & 96 \\
\hline 12. & Devita & 10 & 37 & 47 \\
& Dwi & & & nilai \\
& & & & 94 \\
\hline
\end{tabular}

$\mathrm{KKM}=61$

Dari hasil analisa data hasil test materi mata kuliah dengan metode kontekstualsiklus ketiga dihasilkan data sebagai berikut:

1. Ada 2 mahasiswa yang memperoleh nilai antara $31-40(61-80)$ sehingga $20 \%$ mahasiswa berkategori mempunyai nilai baik.

2. Ada 10 mahasiswa yang memperoleh nilai antara 41 - 50 (81 - 100) sehingga $80 \%$ mahasiswa berkategori mempunyai nilai baik sekali.

3. Dilihat dari ketuntasan proses belajar mengajar secara individu $100 \%$ mahasiswa sudah tuntas dalam memahami materi mata kuliah. Dilihat dari ketuntasan kelas karena $100 \%$ mahasiswa yang mempunyai nilai diatas 31, maka secara keseluruhan kelas telah menampakkan ketuntasan belajar.

5. Refleksi/pembahasan siklus ketiga

Dilihat dari hasil analisa data observasi dan aktivitas belajar dengan metode kontekstual dihasilkan kesimpulan bahwa motivasi dan aktivitas belajar $20 \%$ mahasiswa berkategori baik dan $80 \%$ mahasiswa berkategori baik sekali. Sedang dilihat dari hasil test materi mata kuliah secara individu $20 \%$ mahasiswa berkategori baik dan $80 \%$ mahasiswa berkategori baik sekali. 
Jurnal PINUS: Jurnal Penelitian Inovasi Pembelajaran, 6 (1), 2020, Mochamad Muchson

Dilihat dari tingkat ketuntasan belajar ternyata baik secara individu maupun secara kelas $100 \%$ mahasiswa sudah tuntas belajarnya. Mengapa hal ini bisa terjadi, ada beberapa sebab:

1. Motivasi dan aktivitas mahasiswa dalam mengikuti proses belajar mengajar dengan metode kontekstual berkategori baik dan baik sekali karena mahasiswa terlibat dalam proses pembelajaran baik dari segi fisik maupun mental. Disini terjadi kerja sama antara dosen dan mahasiswa dalam menemukan suatu pengetahuan karena materi mata kuliah dan aktivitas mahasiswa dengan sengaja dikaitkan dengan kehidupan mahasiswa sehingga mahasiswa merasa tertarik. Demikian pula dalam proses belajar dibantu dengan mengamati lingkungan sekitar.

2. Hasil test secara individu $20 \%$ sudah menampakkan hasil dengan kategori baik dan $80 \%$ menampakkan hasil dengan kategori baik sekali. Demikian pula dengan kelas ternyata kelas sudah menampakkan ketuntasan belajar. Hal ini disebabkan karena mahasiswa baik secara individu maupun kelas terlibat bersama-sama dalam proses pembelajaran sehingga secara individu dan kelas secara bersama-sama pulalah mencapai ketuntasan belajar.

3. Metode pembelajaran yang kontekstual menghasilkan mahasiswa yang memahami materi mata kuliah yang melekat erat dibenak mahasiswa karena mahasiswa didorong untuk menemukan pengetahuan itu sendiri dan pengetahuan itu dibentuk dengan mengkaitkan materi mata kuliah dan aktivitas belajar dengan lingkungan mahasiswa, baik lingkungan pribadi, sosial, budaya maupun karakteristik mahasiswa.

4. Untuk itu dosen seyogyanya terus menerus dan secara kontinyu menerapkan metode pembelajaran yang kreatif dan inovatif seperti pembelajaran kontekstual agar materi mata kuliah dan aktivitas belajar mahasiswa dapat menjadi bekal bagi perjalanan hidupnya.

\section{SIMPULAN \\ Kesimpulan}

1. Dilihat dari hasil analisa data observasi dan aktivitas belajar dengan metode kontekstual siklus pertama dihasilkan kesimpulan bahwa motivasi dan aktivitas belajar mahasiswa berkategori cukup. Sedang dilihat dari hasil test materi mata kuliah secara individu 40\% mahasiswa berkategori cukup dan $60 \%$ mahasiswa berkategori baik. Dilihat dari tingkat ketuntasan belajar ternyata secara individu $60 \%$ mahasiswa sudah tuntas belajarnya dan apabila dilihat dari ketuntasan kelas ternyata belum menampakkan ketuntasan belajar. Hal ini disebabkan karena mahasiswa belum terbiasa dengan metode kontekstual. 
Jurnal PINUS: Jurnal Penelitian Inovasi Pembelajaran, 6 (1), 2020, Mochamad Muchson

Mahasiswa terbiasa dengan metode ceramah dimana dosen langsung menjelaskan materi pelajaran sedang dalam pendekatan kontekstual mahasiswa memahami suatu materi mata kuliah melalui keterlibatan yang tinggi dalam pembelajaran.

2. Dilihat dari hasil analisa data observasi dan aktivitas belajar dengan metode kontekstual siklus kedua dimana dosen memberi penekanan pada mahasiswa untuk meningkatkan keterlibatan dalam proses pembelajaran dihasilkan kesimpulan bahwa motivasi dan aktivitas belajar $60 \%$ mahasiswa berkategori baik dan $40 \%$ mahasiswa berkategori baik sekali. Sedang dilihat dari hasil test materi mata kuliah secara individu $60 \%$ mahasiswa berkategori baik dan $40 \%$ mahasiswa berkategori baik sekali. Dilihat dari tingkat ketuntasan belajar ternyata baik secara individu maupun secara kelas $100 \%$ mahasiswa sudah tuntas belajarnya. Hal ini disebabkan mahasiswa sudah beradaptasi dengan pembelajaran kontekstual sehingga motivasi, aktivitas dan nilai testnya meningkat.

3. Dilihat dari hasil analisa data observasi dan aktivitas belajar dengan metode kontekstual siklus ketiga dimana dosen bertindak sebagai motivator dan fasilitator dalam proses pembelajaran dihasilkan kesimpulan bahwa motivasi dan aktivitas belajar $20 \%$ mahasiswa berkategori baik dan $80 \%$ mahasiswa berkategori baik sekali. Sedang dilihat dari hasil test materi mata kuliah secara individu $20 \%$ mahasiswa berkategori baik dan $80 \%$ mahasiswa berkategori baik sekali. Dilihat dari tingkat ketuntasan belajar ternyata baik secara individu maupun secara kelas $100 \%$ mahasiswa sudah tuntas belajarnya. Hal ini disebabkan mahasiswa sudah terbiasa dengan pembelajaran kontekstual sehingga motivasi, aktivitas dan nilai testnya tinggi.

4. Berdasarkan kesimpulan tersebut diatas seyogyanya dosen menerapkan proses belajar mengajar dengan pendekatan kontekstual, karena terbukti pendekatan kontekstual dan meningkatkan motivasi dan aktivitas belajar mahasiswa dan dapat meningkatkan prestasi belajar baik secara individu maupun kelas.

5. Hipotesis penelitian telah dibuktikan yaitu salah satu upaya untuk meningkatkan prestasi belajar mahasiswa adalah dengan menerapkan pembelajaran kontekstual terutama mata kuliah sains yang materi mata kuliahnya dekat dengan kehidupan mahasiswa dan dapat diaplikasikan dalam kehidupan sehari-hari.

\section{Implikasi}

1. Hasil penelitian ini membuktikan bahwa ada perbedaan motivasi, aktivitas dan prestasi belajar mahasiswa dalam pembelajaran kontekstual tiap siklus sehingga dosen perlu melihat tahap-tahap pelaksanaan pembelajaran dengan pendekatan kontekstual.

2. Pendekatan kontekstual dapat diterapkan di kelas apabila ada motivasi yang kuat dari dosen 
Jurnal PINUS: Jurnal Penelitian Inovasi Pembelajaran, 6 (1), 2020, Mochamad Muchson

maupun mahasiswa untuk bersamasama mencari pengetahuan dan penerapannya memerlukan media atau alat bantu pengajaran.

\section{Saran}

1. Dalam menerapkan pembelajaran kontekstual hendaknya dosen menganalisis materi mata kuliah dan mengaitkan dengan lingkungan mahasiswa baik lingkungan pribadi, social, budaya maupun karakteristik mahasiswa. Dengan demikian dosen memerlukan persiapan yang matang baik untuk menyusun perangkat pembelajaran maupun aktivitas pembelajaran.

2. Dalam pembelajaran kontekstual hendaknya mahasiswa mempunyai kesadaran yang tinggi untuk terlibat dalam proses pembelajaran karena pengetahuan dapat ditemukan melalui aktivitas dan kreatifitas yang tinggi dalam proses belajar mengajar.

\section{DAFTAR PUSTAKA}

Johnson, Elaine B. (2009) Contextual Teaching and Learning: Menjadikan Kegiatan BelajarMengajar Mengasyikkan dan Bermakna. (Penterjemah: Ibnu Setiawan). Bandung: MLC.

Kemmis, S. \& McTaggart, R. 1988. The Action Research Planner. Third Edition. Victoria: Deakin University Press.

Muchson, Muchamad (2015). Statistik Deskriptif. Bogor. Gue Pedia.

Nurhadi dan Senduk, Agus Gerrad. (2003) Pembelajaran Kontekstual dan Penerapannya dalam KBK. Malang: Penerbit Universitas Negeri Malang.

Suryanto (2012). Penelitian Tindakan Kelas. Pendidikan dan Latihan Profesi Guru Rayon 43 Universitas Nusantara PGRI 